EPRA International Journal of Economic and Business Review-Peer Reviewed Journal

Volume - 9, Issue -1, January 2021 | e-ISSN: 2347 - 9671| p- ISSN: 2349 - 0187

SJIF Impact Factor (2020): 8.107 || ISI Value: 1.433 || Journal DOI URL: https://doi.org/10.36713/epra2012

\title{
THE COMPANIES ACT 2013 AND ITS SIMILARITIES AND DISSIMILARITIES WITH COMPANIES ACT 1956
}

\author{
Dr. Lavakush Singh
}

HOD , Finance, Department of BBA, Abeda Inamdar Senior College Pune -411001

\section{ABSTRACT}

Article DOI URL: $\underline{\text { https://doi.org/10.36713/epra6050 }}$

The Companies Act, 2013 marks a paradigm shift in India's corporate law regime, and has far reaching implications for both domestic Indian companies and overseas investors with a presence in India. This paper provides a brief analysis of some of the key changes that have been brought about by the 2013 Act which became largely effective on April 1, 2014. Some provisions, however, continue to remain inoperative and are likely to be made effective by the Indian government in due course. This piece makes it easier to understand the changes in the 2013 Act that affect multinational corporations having Indian companies or those looking to make investments in India.

KEY TERMS: Domestic Indian Companies, Overseas Investors, Multinational Corporations \&Investment

\section{INTRODUCTION}

The new Companies Act, 2013 is a landmark legislation with far-reaching consequences on all companies incorporated in India. A part of the Act had already become effective with the notification of 98 sections in September 2013. Further on 26 March 2014, the Ministry of Corporate Affairs has notified most of the remaining sections. These sections have been notified to come into effect from 1 April 2014. The Ministry Of Corporate Affairs has also published the several chapters of the related rules, and the remaining rules in respect of the notified sections are expected to be released by 31 March 2014. This is a landmark legislation that will have a wide ranging impact on corporate India.The Act in a comprehensive form purports to deal with various aspects of corporate India and Indian companies will have to closely examine these developments to develop a clear strategy at ensuring compliance per the new requirements. A part of the Act has already become effective with the notification of 98 sections and the Draft Rules are being made public in phases over this month. This is a landmark legislation that will have a wide ranging impact on corporate India. The Companies Act 2013 intends to promote self-regulation and has also introduced some progressive concepts like One- Person Company, Small Company, Dormant Company, Egovernance, etc. The concept of Corporate Social 
Responsibility has also been introduced to encourage a socially, environmentally and ethically responsible behaviour by companies. Further, the Companies Act 2013 aims to fortify investor protection \& transparency by introducing terms like Insider Trading, Price Sensitive Information, Class Action Suits and other additional disclosures. It also intends to give greater responsibility to the auditors and to widen their role. A National Company Law Tribunal will also be a reality now and therefore the matters which used to linger in courts for years will be swiftly handled by this dedicated tribunal.

\section{OBJECTIVES: THE KEY OBJECTIVES ARE AS FOLLOWS}

1. To study the salient features of Companies Act, 2013.

2. To compare the provisions of companies act 1956 with companies Act 2013

3. To study the effects of companies Act 2013.

\section{RESEARCH METHODOLOGY}

The present study is based on secondary information. Information is collected from online sources. These are as follows: www.montaq.com,www.indiacode.nic.in,www.Ministr $\mathrm{y}$ of Corporate Affairs .gov.in and www.advocatekhoj.com

\subsection{SALIENT FEATURES OF COMPANIES ACT 1956.}

The Key Study features of Companies Act 1956 are as follows:

i. Separate legal existence: A company has a distinct legal entity independent of its members. It can own property, make contracts and file suits in its own name

ii. Perpetual succession: Perpetual succession means continued existence. A company is a creation of the law and only the law can bring an end to its existence

iii. Limited liability: As a company has a separate legal entity, its members cannot be held liable for the debts of the company. The liability of every member is limited to the nominal value of the shares bought by him or to the amount of guarantee given by him.

iv. Transferability of shares: The capital of a company is divided into parts. Each part is called a share. These shares are generally transferable. A shareholder is free to withdraw his membership from the company by transferring his shares. However, in actual practice some restrictions are placed on the transfer of shares.

v. Common Seal: Being an artificial Entity, a company cannot act and sign itself. Therefore, it acts through human beings. All the acts of the company are authorised by its common seal. vi. Separation of ownership and control: Members have no right to participate directly in the day-to-day management of a company.

vii. Voluntary association: A joint stock company is a voluntary association of certain persons formed to carry out a particular purpose in common

viii. Artificial legal person: A company is an artificial person created by law. It exists only in contemplation of law.

ix. Corporate finance: The share capital of a company is generally divided into a large number of shares of small value. These shares are purchased by a large number of people from different walks of life.

x. Statutory regulation and control: Government exercises control through company law over the management of joint stock companies.

\subsection{Key Highlights of Indian Companies}

Act 2013

1. Class action suits for Shareholders: The Companies Act 2013 has introduced new concept of class action suits with a view of making shareholders and other stakeholders, more informed and knowledgeable about their rights.

2. Corporate Social Responsibility: The Companies Act 2013 stipulates certain class of Companies to spend a certain amount of money every year on activities/initiatives reflecting Corporate Social Responsibility.

3. Cross Border Mergers: The Companies Act 2013 permits cross border mergers, both ways; a foreign company merging with an India Company and vice versa but with prior permission of Reserve Bank Of India.

4. Duties of Director defined: Under the Companies Act 1956, a director had fiduciary (legal or ethical relationship of trust) duties towards a company. However, the Companies Act 2013 has defined the duties of a director.

5. Electronic Mode: The Companies Act 2013 proposed E-Governance for various company processes like maintenance and inspection of documents in electronic form, option of keeping of books of accounts in electronic form, financial statements to be placed on company's website, etc.

6. Entrenchment in Articles of Association: The Companies Act 2013 provides for entrenchment (apply extra legal safeguards) of articles of association have been introduced.

7. Fast Track Mergers: The Companies Act 2013 proposes a fast track and simplified procedure for mergers and amalgamations of certain class of companies such as holding and subsidiary, and small companies after obtaining approval of the Indian government.

8. Increase in number of Shareholders: The Companies Act 2013 increased the number of 
maximum shareholders in a private company from 50 to 200 .

9. Independent Directors: The Companies Act 2013 provides that all listed companies should have at least one-third of the Board as independent directors. Such other class or classes of public companies as may be prescribed by the Central Government shall also be required to appoint independent directors.

10. Indian Resident as Director: Every company shall have at least one director who has stayed in India for a total period of not less than 182 days in the previous calendar year.

11. Liability on Directors and Officers: The Companies Act 2013 does not restrict an Indian company from indemnifying (compensate for harm or loss) its directors and officers like the Companies Act 1956.

12. Limit on Maximum Partners: The maximum number of persons/partners in any association/partnership may be upto such number as may be prescribed but not exceeding one hundred. This restriction will not apply to an association or partnership, constituted by professionals like lawyer, chartered accountants, company secretaries, etc. who are governed by their special laws. Under the Companies Act 1956, there was a limit of maximum 20 persons/partners and there was no exemption granted to the professionals.

13. More power for Shareholders: The Companies Act 2013 provides for approvals from shareholders on various significant transactions.

14. National Company Law Tribunal: The Companies Act 2013 introduced National Company Law Tribunal and the National Company Law Appellate Tribunal to replace the Company Law Board and Board for Industrial and Financial Reconstruction..

15. One Person Company: The Companies Act 2013 provides new form of private company, i.e.,

\begin{tabular}{|c|c|c|}
\hline Descriptions & 1956 & 2013 \\
\hline Parts & 13 & No \\
\hline Chapters & 26 & 29 \\
\hline Sections & 658 & 470 \\
\hline Schedules & 15 & 7 \\
\hline $\begin{array}{l}\text { Minimum \& maximum No of } \\
\text { shareholders for Private Ltd } \\
\text { Companies }\end{array}$ & $2 \& 50$ & $1 \& 200$ \\
\hline
\end{tabular}

Table 1:Comparative details of old and New companies Act

Source :www.legalserviceindia.com one person company. It may have only one director and one shareholder. The Companies Act 1956 requires minimum two shareholders and two directors in case of a private company.

16. Prohibition on forward dealings and insider trading: The Companies Act 2013 prohibits directors and key managerial personnel from purchasing call and put options of shares of the company, if such person is reasonably expected to have access to price-sensitive information.

17. Prohibits Auditors from performing NonAudit Services: The Companies Act 2013 prohibits Auditors from performing non-audit services to the company where they are auditor to ensure independence and accountability of auditor.

18. Rehabilitation and Liquidation Process: The entire rehabilitation and liquidation process of the companies in financial crisis has been made time bound under Companies Act 2013.

19. Rotation of Auditors: The Companies Act 2013 provides for rotation of auditors and audit firms in case of publicly traded companies.

20. Serving Notice of Board Meeting: The Companies Act 2013 requires at least seven days' notice to call a board meeting. The notice may be sent by electronic means to every director at his address registered with the company.

21. Women empowerment in the corporate Sector: The Companies Act 2013 stipulates appointment of at least one woman Director on the Board (for certain class of companies).

\subsection{Similarities and dissimilarities between Companies Act 1956 and the Companies Act, 2013: Indian Companies Act 2013 has fewer sections (470) than Companies Act 1956 (658). The new act empowers shareholders and gives high value for Corporate Governance. This can be understood with the help of a table given below.}




\section{Effects of Companies Act 2013 : The main Implications of the Companies Act 2013 are explained below: \\ i) Constitution of the Board}

The 2013 Act has made a significant change in the manner in which boards of companies must be constituted. It is mandatory that at least one director must be a resident in India for a minimum period of 182 days during the preceding calendar year. Moreover, all listed companies and certain other classes of companies as prescribed under delegated legislation would also need to have at least one woman director on their boards. All listed Indian companies and unlisted companies satisfying certain conditions are now required to have at least one third of their board comprising of "independent directors

ii) Decision-Making Power of the Board

Unlike under the Indian Companies Act 1956 ("1956 Act"), where an ordinary resolution (requiring a simple majority of shareholders) was sufficient, under the 2013 Act, certain powers of the board of directors can now only be exercised subject to a favourable special resolution (requiring a three-fourth majority of shareholders) being passed.

\section{iii) Related Party Transactions}

The range of related party transactions under the 2013 Act has been significantly widened compared to the provisions of the 1956 Act. Under the 2013 Act, a shareholder of the company, who is a related party visà-vis a counter party in such a transaction, is not permitted to vote while approving the transaction. The 2013 Act also specifically prohibits forward contracts and put or call options between the directors/key managerial personnel of a company and the company or any holding, subsidiary or associate company iv)Corporate Social Responsibility

The 2013 Act has ushered in certain innovative provisions relating to corporate social responsibility. A company that has a net worth of at least Rs 5 billion or a turnover of at least Rs 10 billion or a net profit of at least Rs 50 million during any financial year will be required to constitute a "Corporate Social Responsibility Committee" with three or more directors to frame and oversee the company's general policy and specific corporate social responsibility activities.

\section{v) Inter-Corporate Loans}

The 2013 Act has imposed several onerous conditions for inter-corporate loans. Under the 2013 Act, a special resolution (requiring a three-fourth majority of shareholders) is required for a loan exceeding the prescribed threshold of 60 percent of the paid-up share capital, free reserves and securities premium account of the company, or 100 percent of free reserves and securities premium account of the company, whichever is higher.
vi)Capital Raising.

Under the 1956 Act, in the case of preferential allotment, unlisted public companies needed shareholder sanction and private companies needed board sanction, and there were scant other compliances. However, under the 2013 Act, these companies must also prepare an offer letter which will require some financial and other information to be included. In the context of the rights issue process, the pricing of resultant securities would need to be determined upfront even in the case of private companies.

\section{vii)Insider Trading}

Foreign investors must be cautious that the 2013 Act introduces a fresh provision relating to insider trading, a concept that was previously dealt with by a separate regulation for listed Indian companies enacted by the Securities and Exchange Board of India and not under the 1956 Act. Under the 2013 Act, all persons, including any director or key managerial personnel of a company, are prohibited from indulging in insider trading.

\section{viii) Buy-Back of Shares}

Under the 1956 Act, companies could do multiple buybacks of shares in the same financial year except in certain specific facts where there was a cooling off period of one year. However, now the 2013 Act requires a mandatory one-year time period between any type of buy-back, even if the buy-back was achieved through a scheme approved by an Indian court.

\section{ix) Minority Squeeze-Out}

The 2013 Act now explicitly deals with the issue of buying out the minority shareholders of a company. In a situation where an acquisition results in the acquirer holding 90 percent of the issued share capital of the company, it shall be obliged to inform the company of its desire to purchase the minority shareholding of that company at a price determined according to the provisions of the 2013 Act. This is a key change and significant departure from the 1956 Act, which did not have such a provision

\section{x) Layered Investments Through Subsidiaries}

The 2013 Act makes a significant departure from the 1956 Act by specifically mandating that investments can no longer be made through more than two layers of investment companies, except in certain specified.

xi) Mergers

The 2013 Act significantly alters the manner in which mergers may be effected, with an objective of making them less time-consuming and providing more flexibility. In this context, the 2013 Act has introduced two concepts novel to Indian law, i.e., "fast track mergers" and "cross border mergers". The 1956 Act permitted the mergers of foreign companies into Indian companies, but did not allow the converse. policy. 


\section{xii) Class Action Suits}

The Companies Act 2013 Act now specifically provides for class action suits brought by: (i) members; or (ii) depositors of a company, where they are of the opinion that the management or conduct of the affairs of the company is being conducted in a manner prejudicial to the interests of the company or its members or depositors.

xiii) Enforcement of Shareholders Agreement and Entrenchment

Under the 1956 Act, the articles of association of a company could only be altered by a resolution passed by three-fourth of its shareholders. The 2013 Act has now specifically validated the idea of entrenchment, and therefore, all such contractual agreements by shareholders now have legislative recognition. This will provide much-needed flexibility for investors to specify that certain provisions of the articles of a company may only be altered if special conditions or procedures are complied with.

6. CONCLUSION: The present Companies Act is transparent, business friendly and invited more FDI into various sectors of economy. The favourable Labour laws made foreign as well as Indian investors attracted towards Indian companies. This paved the way for bright future for Indian economy in terms of employment, GDP, per capita income etc.

\section{REFERENCES}

1 www.montaq.com

2. $w w w . i n d i a c o d e . n i c . i n$

3. www.Ministry of Corporate Affairs .gov.in

4. www.advocatekhoj.com

5. www.indiankanoon.org

6. www.clearias.com

7. www.toppers.com 